\title{
Feminismo oportunista ou oportunismo feminista do mercado editorial
}

\section{Histórias de mulheres.}

MONTERO, ROSa.

Rio de Janeiro: Agir, 2008. 223 p.

A paixão com que a espanhola Rosa Montero escreve não combina com o senso de oportunidade que recobre o lançamento de Histórias de mulheres, no Brasil. Escrito em 1995, o livro é um conjunto de 15 pequenas biografias de pelo menos 18 mulheres pouco ou bastante famosas mundo afora; Simone de Beauvoir e Frida Kahlo estão entre elas. Os relatos são cuidadosos e, como a própria autora anuncia na introdução, não têm pretensão acadêmica. Não há rigor territorial ou temporal na escolha, que se limitou a considerar sentimentos de Montero. "Mais que escolher eu mesma as protagonistas, foram elas que me escolheram: vou falar daquelas mulheres que em algum momento falaram a mim" (p. 28).

São mulheres diversas: loucas, doentes, lésbicas, libertárias, oprimidas, boas, más, talentosas, incoerentes. Entretanto, não é difícil encontrar semelhanças entre uma e outra. Em essência, elas representam uma força feminina e feminista, cada uma em seu tempo e espaço. São histórias de ruptura, de enfrentamento, temperadas, todas elas, com um quê revolucionário, rebelde e artístico, seja na linguagem literária que Montero emprega, apesar da crueza de conteúdo de alguns relatos, seja na proximidade entre as biografadas e o universo ficcional.

A mais que famosa, e tão criticada, escritora Agatha Christie abre o livro. De acordo com a autora, a sua luta, predominantemente interna, de organizar o mundo lhe rendeu quase 100 obras literárias, dentes estragados e muitos quilos extras. A pequena biografia mostra uma mulher em busca de ordenar o que está à sua volta - daí os seus romances serem tão amarrados -, mais do que isso: em busca de tornar perfeita a sua própria vida. "Agatha Christie passou a vida ocultando coisas, dissimulando defeitos, alterando virtudes, construindo de si mesma uma comovedora personagem imaginária" (p. 37). No outro extremo, a "bruxa" Laura Riding tinha como objetivo de vida a fragmentação de estruturas sólidas, como a família, em nome do amor intenso. Segundo Montero, com 
o poeta britânico Robert Graves dividiu obras literárias, alcova e casa; isso tudo sem que a esposa de Graves, a pintora Nancy Nicholson, e seus quatro filhos fossem apartados do convívio de ambos. A situação, somada aos intentos de trazer ao grupo o poeta irlandês Geoffrey Phibbs, leva a uma tentativa malsucedida de suicídio e a um desfecho inesperado. A escultora Camille Claudel que a autora nos apresenta foge da imagem a que estamos acostumadas, de discípula e amante do grande Auguste Rodin e de irmã louca do poeta Paul Claudel. Ela é exemplo de como a história, muitas vezes, encarrega-se de relegar às mulheres papéis secundários, coadjuvantes. "Ou amante de um ou irmã do outro, mas nunca ela mesma: é claro que seu destino foi desaparecer" (p. 190). A Camille apresentada no livro é uma grande escultora antes de Rodin, autodidata e chega mesmo, segundo Montero, a influenciar o escultor francês.

O que não é de domínio público, apesar de as biografias já publicadas não esconderem os detalhes, gera curiosidade. E, diante de Histórias de mulheres, o olhar curioso é inevitável. $A(0)$ leitora(r) se vê enfeitiçada(o) pelo voyeurismo latente das histórias narradas pelo olhar encantado da autora. O senso de oportunidade do livro, como produto à venda, evidencia-se primeiramente nesse ponto. $O$ interesse pelos bastidores de famosos ocupa os dois extremos pilares do consumo capitalista: oferta e procura. Balizado por essa estrutura, o lançamento do livro de Montero no Brasil cumpre ainda outros objetivos: ser um conjunto curto e dinâmico de biografias e angariar leitores com todo o seu aparato publicitário (capa, disposição em livrarias etc.).

As histórias, apesar de algumas se basearem em pesquisas cuidadosas e sobre material pouco acessível, estão registradas em biografias maiores, exclusivas (Montero cita e adjetiva pelo menos uma para cada um de seus relatos). Não há interesse que se configurem relatos absolutos, totais. $\mathrm{E}$, se o livro se afasta do rigor acadêmico e da objetividade jornalística (se é que ela existe), ele não passa de um aglomerado de pequenas e interessantes histórias com opinamento declarado - e muitas vezes exagerado, cheio de clichês e julgamentos - da autora. Ao público acadêmico o interesse pelo conteúdo não existe, ou não está entre os motivadores do lançamento, dada a superficialidade da abordagem. Há que se concluir, portanto, que o público mirado é o mesmo consumidor dos "livros de variedades" ou auto-ajuda. E não há julgamento de valor nessa setorização providencial que fazemos e, sim, apenas a constatação de que se criou algo vendável para um público relativamente grande. A capa é chamativa, com a figura de uma grande boca vermelha, clichê que evoca feminilidade e lembra um sofá moderno (daí a idéia de acolhimento é visitada), e os volumes ocupam lugar de destaque em livrarias.

Quando nos propomos a sublimar o caráter oportunista do mercado, com todas as suas artimanhas para estimular o consumo acéfalo e desenfreado, podemos vislumbrar um ponto positivo: para a capilaridade das questões de gênero, o mercado pode ser visto como aliado. Se ainda existe a dificuldade de inserção de discussões aprofundadas em âmbito social e doméstico (e até no acadêmico) ou mesmo dificuldade de apresentação de pontos de vista diferentes no dia-a-dia - ao se escutarem piadas ou referências preconceituosas - em relação à questão de gênero, especificamente à condição feminina, essas pequenas incursões podem, ainda que oportunistas, contribuir para uma mudança de paradigmas. A sutileza, e eu diria até superficialidade, com que chega à tona o mote feminista por meio de Histórias de mulheres pode significar o meio possível de propor um olhar distinto do senso comum diante do tema. E, se o público tende a ser mais abrangente do que o já acostumado gueto da academia, melhor. Afinal, excetuando-se os desnecessários acenos da autora com a inserção de sua opinião, vez por outra e de modo descuidado do ponto de vista da objetividade, o conjunto de relatos é, em si, um apanhado importante, um conjunto significativo de experiências pessoais que contribuíram para que os papéis sexuais deixassem de ser entendidos como resultado "natural", físico e biológico. E se não há evolução linear, como ressalta a autora, pode-se verificar que a passividade feminina absoluta nunca existiu e que a consolidação de um ethos mais acolhedor de diferentes visões e efetivamente diverso depende, ainda, de muitas rupturas.

Liana Aragão

Universidade de Brasília 